This chapter describes a university-based migrant farmworker outreach and education program in Michigan and the difference it has made in the rural community it serves, as well as in the lives of the university students who have participated in it.

\title{
University and Community Collaborations in Migrant ESL
}

\author{
John McLaughlin, Maria Rodriguez, Carolyn Madden
}

Migrant English as a Second Language (ESL) has been an important form of rural adult education in the United States for decades. It has been recognized as a distinct subfield of both adult education and ESL at least since the mid-1960s, when crucial pieces of federal legislation were passed. Also, activist and professional associations were formed then that engaged in migrant education and/or ESL, for example, Teachers of English to Speakers of Other Languages (TESOL) and the Farm Labor Organizing Committee, both founded in 1966. Migrant ESL is a unique form of adult education in that most programs are carried out at migrant farm camps in rather remote, rural locations through a wide range of organizations and funding streams.

This chapter provides a national and historical overview of rural and migrant ESL. The educational needs of the growing population of seasonal, migrant agricultural workers are discussed and situated in relation to the growth of adult education, literacy education, and ESL as professions in the United States. Then, the majority of this chapter describes and evaluates a migrant farmworker outreach and education program created at the University of Michigan at Ann Arbor and brought to migrant camps in Lenawee County in rural southeastern Michigan. This program, now in its tenth year, has had an important impact on both the university community and the Lenawee County organizations that serve the migrant farmworker populations there. We offer this account as a model for mutually beneficial collaboration among several groups of stakeholders who have provided

\section{(7)WILEY}


migrant ESL and bilingual health and safety education to adults in rural areas in an era of continuing budget cuts for both adult education and migrant education.

\section{Migrant ESL and Its Relation to Rural Adult Education}

Rural ESL began to emerge as a distinct area of ESL in the past decade as migrant agricultural workers settled in rural communities to take yearround jobs. In rural counties around the country, the local Anglo-white population and labor force has decreased due to death, retirement, lower birth rates, and migration to urban and suburban areas, while the Latino and other immigrant workforce moving in has been younger and families have more children. Increasingly there have been more job openings in industries such as nurseries, meatpacking, other forms of food processing, and other service work such as lawn maintenance, as suburban sprawl edges out into formerly rural areas. Berube (2002) cites that 40 percent of limited-Englishproficient youth are in rural schools, and the English Language Learner (ELL) population has more than tripled since 1990 from 1.4 million to 4.5 million students in $\mathrm{K}-12$ who are classified as English language learners by the U.S. Department of Education. Demand for training in ESL curriculum and instruction as well as in multicultural education is burgeoning everywhere in rural states and counties across the United States. To address this need, the National Clearinghouse for English Language Acquisition (2006) has recently put out a resource guide for rural education.

The 1960s were a turning point and a point of convergence of developments in adult education, ESL, migrant education, and migrant farmworker activism. Migrant ESL as a distinct subfield of education and ESL arose in the 1960s with the establishment of federally funded migrant education programs and the emergence of ESL as a profession. For example, the U.S. federal government funded Migrant Education Program for school-age migrant farm children began in 1963 (see www.escort.org for further information on the nature of K-12 migrant education). Federal funding for adult education on a national basis began in 1966 (Sticht, 2002). ESL also began to take off as a recognized profession with degree-granting programs (usually a master's degree in TESOL) and various forms of certification and licensure in the 1960s. The end of this decade was also a period of farmworker labor organizing in California and the Midwest, and undoubtedly many paid and volunteer (student) organizers tutored the mostly Spanish-speaking migrant farmworkers while organizing them. While the primarily Spanishspeaking migrant farmworker population continued to grow, the 1970s and 1980s were a period of growth in local adult education programs that served them, including literacy councils and organizations that were usually regional or county based. Other sources of migrant education for adults have included federally funded Migrant Head Start programs for parents and 
state university extension programs. As with adult education in general, migrant ESL programs have also periodically or frequently experienced fluctuations in federal and state funding due to economic and political vicissitudes. Furthermore, migrant ESL programs are usually seasonal, or run only in the summer in the northern United States, and staff turnover is high as qualified and committed instructors obtain more secure or permanent positions. University service-learning programs are probably the newest arrival on the migrant education scene, and we are aware of only a few other programs around the country hosted in a variety of university schools and departments. For example, the law clinic at the University of Tennessee at Knoxville Law School had a migrant farmworker outreach program, as did the School of Social Work at the University of South Carolina, at least between 2003 and 2005.

Migrant ESL is rooted in both communicative ESL methodology and the popular education principles found in some basic adult literacy classes, often combining Freirean popular education methods, bilingualism, and arts. A published exemplar of this hybrid approach and these methods is documented by Kalmar (2001) based on his experience with Mexican farmworkers in Cobden, Illinois, in the early 1980s. In mainstream ESL, communicative language teaching became the dominant paradigm by the 1970s. It focuses on oral communication as well as basic literacy, incorporating features such as self-contained lessons or modules and materials easily adapted to low-literate, highly mobile populations (see Osterhaudt and Wilkin, 1992, for a good example). Another element that distinguishes this subfield is its setting: migrant ESL is usually carried out at farm camps, out in the open or in makeshift classrooms (barns, trailers, tents) without the usual amenities of a school building. A final distinguishing factor is the range of people who teach migrant ESL, from church volunteers to union and community organizers, from high school and university students to paid community college educators. Church volunteers teaching basic English and Bible stories are among the main providers and sponsors of social services for migrant farmworker families in southeast Michigan, as well as competitors for evening time with other migrant outreach groups.

\section{Migrant Farmworkers in the United States and Their Educational Needs}

It is hard to get an accurate count of the 2 to 3 million seasonal and migrant farmworkers in the United States. The U.S. Department of Agriculture estimates that there are at least 1 million migrant male and female adults and 500,000 children and youth who engage in seasonal or temporary agricultural labor, some perhaps having engaged in this work for decades (Thompson and Wiggins, 2002). Due in part to the rural location of employment and residence, these farmworkers have been among the most peripheral and invisible in our society despite their cause-célèbre status among progressive 
urban consumers and social activists during periodic boycotts of agricultural and other food products (among them grapes, pickles, Campbell's Soup, and Taco Bell). Their marginality in our society is aggravated by the undocumented immigrant status affecting about 50 percent of them. At any given site, or farm camp, the annual turnover among this population is extraordinary-about 30 to 40 percent of the workforce. Still, approximately half of this population has settled into a yearly pattern of migrating from southern states to the same northern states. Of the 20 million Mexican-born residents of the United States, perhaps half of them have engaged in seasonal agricultural labor at some point in their stay, and that form of employment is an important point of entry in our society. However, given the vast number of migrants and their geographical spread, the current array of adult education services provided by federal and state governments does not adequately serve this population (Rothenberg, 1998).

Given the hegemonic status of English (proficiency and literacy) as a condition for obtaining most of the best-paying jobs in the United States, the educational needs of this population are enormous for those who wish to enter the mainstream of education and employment. The disrupted schooling of children and youth perpetuates the migrant farmworker lifestyle or life cycle. Having a limited range of options for education before and advancement during employment, migrant farmworkers are not to be criticized for their choices. It is the persistent poverty and exploitation of farmworkers in relation to established labor standards governing employment and working conditions that other industries and occupations enjoy that should be criticized (see Rothenberg, 1998; Thompson and Wiggins, 2002). Furthermore, the United States now has one of the largest Spanish-speaking populations in the Western Hemisphere but lacks a coherent policy for bilingual education and first-language literacy support, even in most adult education programs. Almost 90 percent of migrant farmworkers and their families speak Spanish or an indigenous language of Mexico or Central America. Moreover, although most rural migrant services are offered bilingually (and for indigenous-language native speakers, Spanish is already a second language), there are few other Spanish-language resources in most rural U.S. communities, which creates other obstacles to participating in adult education in English. Yet migrant farmworkers are keen on educational opportunities that will lead to more secure or stable jobs with better pay and working conditions (Arceo, Kusserow, and Wright, 2002).

In general, most migrant farmworker adults, the majority of whom have emigrated from Mexico, have limited education. In Mexico, only primary school is compulsory, although not universally enforced, and secondary school involves fees and long-distance travel for many in rural and impoverished communities. The average grade level of education of Mexican immigrants is about sixth grade for adults who have emigrated here and ninth grade for children who have grown up here. Even these average years 
of schooling conceal a wide range because many Mexican college graduates have engaged in agricultural labor in the United States, and many Mexican children do not attend or drop out of elementary school due to poverty and migration. The ninth-grade average level of education for children indicates how serious the dropout problem is for migrant students in the United States, and how adult education here is failing to meet their needs as (young) adults, although there are several initiatives for current migrant young adults such as the College Assistance Migrant Program and the High School Equivalency Program (Arceo, Kusserow, and Wright, 2002). Our government and society have an obligation to provide educational opportunities for an otherwise talented and hard-working group of people. In the absence of U.S. efforts, the Mexican government has been providing basic literacy and other educational materials to American school districts and community organizations through the Instituto de los Mexicanos en el Exterior and its network of consulates around the United States (see www.ime.gob.mx for more information in Spanish).

\section{The Migrant ESL and Outreach Program at the University of Michigan, 1996-2006}

Readers may be surprised to realize that Michigan has been among the top five of migrant-receiving states and has had between forty-five thousand and ninety thousand migrant farmworkers every summer for decades (probably seventy-five thousand or higher during peak harvest periods). Michigan leads the country in several agricultural crops that must be quickly and delicately harvested by hand, including cherries, pickle cucumbers, and other fruits; vegetables; and flowers. Most of this farmworker population works along Lake Michigan in western Michigan, but there are pockets in central and eastern Michigan that rely heavily on migrant farmworkers (Rochin, Santiago, and Dickey, 1989).

While adult education and ESL services have been developed to serve this population since the 1960s, by the mid-1990s state funding for adult education was drastically reduced by the Republican administration in Michigan. This hurt all adult education and seriously diminished services to the state's migrant population. In an effort to find support for these programs, a migrant educator from the Lenawee County Intermediate School District contacted universities in southeastern Michigan to plead for programmatic and financial support. The English Language Institute (ELI) at the University of Michigan responded with a voluntary effort between 1995 and 1996, which resulted in the recruitment of a linguistics student and an employee interested in Latin American issues. Through the efforts of the ELI's librarian, materials and books were collected for a program in the summer of 1996. With the help of Lenawee County's Community Action Agency and Literacy Council, the program reached six camps in southeast Michigan serving families and single farmworkers. In a year's time, the program was 
institutionalized, and the College of Literature, Science and Arts and its Office of Multicultural and Academic Initiatives agreed to support the program during the spring and summer semesters for the next four years, from 1997 until 2000.

At the start, the Migrant Outreach Program was facilitated by the ELI and academically supported by the Ginsberg Center for Community Service Learning, where the nationally renowned Michigan Journal of Community Service Learning is published. The University of Michigan, one of the nation's leading public research universities, took an early lead in the servicelearning movement that grew on American campuses in the 1980s and 1990s. Support has been given to many schools, departments, and institutes on campus to create academic service-learning courses. Academic servicelearning courses integrate the service-learning experience as a core content or text of the curricula, while requiring substantial academic preparation before entering the field and continuous oral and written reflection of the experience. The service experience is integral, not extracurricular or even cocurricular. In particular, the migrant ESL program incorporated the expertise of many of the ELI faculty, who provided workshop support for the undergraduate students who participated in learning and teaching ESL and migrant culture for academic credit. Until recently this course was also one of the few that provided a supervised practicum with actual ESL teaching (for credit) for liberal arts undergraduates at the University of Michigan. The program made every attempt to collaborate with other departments for support and expertise, particularly those with migrant outreach programs of their own, such as the Residential College, a select, interdisciplinary liberal arts program; the School of Dentistry; and the School of Medicine's Departments of Psychiatry and Pediatrics.

Besides academic community service-learning, other principles of the Migrant Farmworker Education and Outreach Program have been community collaboration and bilingualism. Fortunately, since the 1970s, Michigan has had a proactive Migrant Services Division in its Department of Human Services, and every region of the state has a Migrant Resource Council. The Southeastern Michigan Migrant Resource Council is one of the largest, and its wide area serves the largest number of migrant farmworkers outside western Michigan. Staff in our program have regularly attended meetings and coordinated with other agencies and organizations through this council to make sure not to interfere with and crowd out other programs at the farm camps and to combine outreach visits as educational for both the ESL learners and the university students (for example, health lessons when the mobile clinics visit the camps).

We have been committed to prolonged engagement and mutual benefit when writing grant proposals and sharing funding, resulting in initiatives such as the Southeastern Michigan Migrant ESL Resource Booklet, a bilingual arts and literacy program for children, and several smaller initiatives in health and arts education. These projects were funded by the University of 
Michigan Center for Research on Learning and Teaching, the Michigan Campus Compact, the Ginsberg Center for Community Service Learning, and a Michigan Department of Education-administered McKinney-Vento Education of Homeless Children and Youth subgrant. Furthermore, the courses have been cotaught by ESL and Spanish-language educators for the past five years, and the Southeastern Michigan Migrant ESL Resource Booklet is bilingual. The booklet (available at http://www.lsa.umich.edu/eli/ instruction/workers/) provides a good sense of what we do in our program.

\section{A Decade of Migrant ESL and Outreach at the University of Michigan}

This encounter by liberal arts undergraduates at an elite public university with "rural Michigan/America" has had a positive impact on both students' lives (in terms of their career choices and directions after graduation) and the wider community served by the University of Michigan's Migrant Farmworker Outreach and Education Program (in terms of continuity and collaboration). It is less certain how migrant farmworkers themselves have benefited from our program, as there is only so much that can be done in roughly ten lessons where turnout is affected by the vicissitudes of weather, as well as home and work responsibilities. Nevertheless, this uncertainty is not an argument for discontinuing the program but rather an ongoing inquiry into what would truly serve the educational needs of the migrant farmworker population in our area.

The program has evolved organically with two distinct phases thus far, and perhaps entering a third as faculty coordinators turn over every five years or so. It is a physically and emotionally intense experience for both university students and instructors, one that requires working evenings and getting home late, after 11:00 P.M. Perhaps one interesting way to look at how the program has changed over time is to see how the migrant farmworkers have been served.

Originally there were two separate programs: ESL and Spanish Outreach. The ESL program worked by primarily teaching English to adult men. In the initial stages, visits were made to the various camps in order to solicit support from the farm owners and then to canvass workers and their families, gathering commitments from the workers to attend classes. While migrant workers are legally eligible to have visitors at their housing site, the situation in migrant camps is a particularly sensitive one, with many farm owners cautious about publicizing the housing and living conditions of migrant workers. The outreach program in Spanish also visited the same camps, but its focus was to provide information to the migrant population in their native language, ensuring that the families understood and were able to participate in the discussions. This course tended to work with both adults and children, as it was necessary to devise activities to keep the children occupied while the students provided presentations on health issues 
and conducted pesticide safety trainings with adults or served as translators for medical clinics.

Due to the logistics of funding, staffing, and coordination, as well as a renewed commitment to bilingualism as a critical approach to ESL, those two programs were combined in 2002. The new combined course no longer provided health information, but the students continued to be trained in Spanish to present pesticide safety issues and provide basic medical translation. We realized that to involve women in the ESL program, we needed to offer separate classes from the men as well as to teach the children simultaneously, which our combined program started doing fully by 2004. In this way, women were freed from familial responsibilities and were able to focus on their lessons, and the teaching interns were able to design lesson plans that reflected women's and men's diverging needs and interests as to language use. The children's classes have fully taken root in the past three years, although adult women's classes have been harder to sustain consistently at all three camps. A next direction would be to incorporate more vocational or career-oriented lessons in the program. Automotive maintenance is very popular, but few university students appear to have much skill (or vocabulary) in this area.

Over the years, the migrant farmworkers have come to expect our program at the three main camps in Lenawee County. In addition, the coordination of the wide array of services we provide or tie in with has been a primary strength. The success of the summer program has been measured along many variables. The number of migrant students attending the evening classes, after a long day picking fruits or vegetables, was a significant marker for the individual intern teacher's feeling of success (depending on the year and the camp, overall turnout varies from ten to twenty-five students every visit). Migrants themselves voiced how much they valued the intern's work by offering to pay for evening ESL classes after the official academic course was completed. In fact, many undergraduates have continued teaching as volunteers with "their students" beyond the academic semester.

For the ELI and the university, the integration of experience with academic reflection for the student interns was another measure of success. The students' reflection papers were a significant testimony to the influence of the experience on their lives and academic careers. We require a research paper in the spring on an issue affecting migrant farmworkers in the United States, but in the summer term, many students opt to do a creative art project with a shorter essay at the end of the course because words alone cannot capture or convey their experience. One undergraduate in the College of Literature, Science and Arts, who was determined to go to law school, delayed the professional school experience for a year to volunteer to teach ESL abroad. Others expressed an increased awareness and a deeper understanding of injustices and poverty and their many causes here at home. Still others looked for more global venues, such as the Peace Corps, in which to continue their experience and education. Several students have created 
campus and community organizations to serve Spanish-speaking migrant and immigrant workers in the area. From creating an arts program to an academic tutoring program, to a workers' center with ESL programs run jointly with a church, our students have done extraordinary things with their experience. In addition, the local migrant advocacy community and the farmworkers themselves enjoy their interaction and connection with our university program. Nevertheless, it is heartbreaking to leave the camps for the last time every August, knowing we have made at most a small difference in the lives and education of the farmworkers and children themselves.

Our effect on the migrants' language development has always been less satisfying. In spite of an enormous effort and commitment by staff and faculty, the interns are given a short course in teaching ESL and asked to teach in very difficult and challenging situations. The ELI and Linguistics Department sponsored a research project to evaluate and assess the value of the program on the language of the migrants. While it was obvious that within this short period of time language was not much improved, the impact of the connections and the commitment served to increase the farm growers' appreciation for the university's interest and presence. It also created expectations on the part of the migrants that there was support from outside the farming community for their plight and their well-being. What gets developed is probably the confidence that comes from sympathetic, at times bilingual, interactions with diverse Americans.

A tacit attraction of the migrant outreach program for university students and faculty is the possibility to enter a different world of rural farm communities in Michigan that is both a culture shock and a pleasure (perhaps nostalgia for America's agricultural past?). There is a sense of traveling back in time while driving along Highway 12, the old stagecoach road between Detroit and Chicago, with its many farms and several abandoned farmhouses and collapsed barns along the way. Another shock on reentry into downtown Ann Arbor as the vans unload at night is that such large concentrations of cultural and linguistic others exist in that world that we are unaware of as we buy the food they harvest. This brief summer experience connects us with the rural, agricultural roots that most of us share at some point in our family trees. The bonds we form among program participants, including the migrant farmworkers, though brief, are intense and profound.

\section{References}

Arceo, R., Kusserow, J., and Wright, A. "Understanding the Challenges and Potential of Migrant Students." In C. Thompson Jr. and M. Wiggins (eds.), The Human Cost of Food. Austin: University of Texas Press, 2002.

Berube, B. "Three Rs for ESL Instruction in U.S. Rural Schools: A Test of Commitment." TESOL Matters, 2002, 12(4).Retrieved June 23, 2007, from http://www.tesol.org/ s_tesol/sec_document.

Kalmar, T. M. Illegal Alphabets and Adult Biliteracy: Latino Migrants Crossing the Linguistic Border. Mahwah, N.J.: Erlbaum, 2001. 
National Clearinghouse for English Language Acquisition. "Rural Education." 2006. Retrieved June 23, 2007, from http://www.ncela.gwu.edu/resbout/rural/index.html.

Osterhaudt, B., and Wilkin, B. "The Glide, the Sting, the Rescue: ESL Instruction for Migrant Farmworkers." TESOL Journal, 1992, 2(1), 17-21.

Rochin, R. I., Santiago, A. M., and Dickey, K. S. Migrant and Seasonal Workers in Michigan's Agriculture: A Study of Their Contributions, Characteristics, Needs and Services. East Lansing: Julian Samora Research Institute, Michigan State University, 1989.

Rothenberg, D. With These Hands: The Hidden World of Migrant Farmworkers Today. Berkeley: University of California Press, 1998.

Sticht, T. G. "The Rise of the Adult Education and Literacy System in the United States, 1600-2000." 2002. Retrieved Apr. 30, 2007, from www.ncsall.net/?id=576.

Thompson, C. D., and Wiggins, M. F. The Human Cost of Food: Farmworkers' Lives, Labor and Advocacy. Austin: University of Texas Press, 2002.

JOHN MCLAUGHLIN is an educational specialist in the Consolidated Federal Program Support Division of the Minnesota Department of Education and was the coordinator of the University of Michigan's Migrant Farmworker Outreach and Education Program from 2002 to 2006.

MARIA RODRIGUEZ is a lecturer in Spanish in the Residential College and coordinator of the Migrant Farmworker Outreach and Education Program at the University of Michigan, Ann Arbor.

CAROLYN MADDEN is a senior lecturer and associate director for curriculum and instruction at the University of Michigan English Language Institute. She founded the English Language Institute's Migrant Worker Program in 1996. 